\title{
Larval development and fatty acid composition of Ostrea edulis (L.) fed four different single diets from conditioning to pre-settlement
}

\author{
Gonzalez-Araya Ricardo ${ }^{1,2}$, Robert René ${ }^{2,3,{ }^{*}}$ \\ ${ }^{1}$ Comite Reg Conchyliculture Bretagne Nord, Morlaix, France. \\ 2 Ifremer, Lab Physiol Invertebres Marins, LEMAR, UMR 6539, Plouzane, France. \\ ${ }^{3}$ Ifremer, ZI Pointe Diable, Ctr Bretagne, Unite Littoral, Plouzane, France. \\ *Corresponding author : René Robert, email address : rene.robert@ifremer.fr
}

\begin{abstract}
:
Survival, growth and fatty acid composition of Ostrea edulis larvae (L.) fed four different single species, microalgal diets, Tisochrysis lutea $(T)$, Chaetoceros neogracile $(\mathrm{Cg})$, Skeletonema marinoi $(\mathrm{Sm})$ or Tetraselmis suecica (Ts) from broodstock to pre-settlement, were studied. Lower larval growth (5.5 $\mu \mathrm{m}$ to $6.5 \mu \mathrm{m} / \mathrm{d}$ ) was recorded in progeny continuously fed single $S$. marinoi or $T$. suecica, whereas good growth was achieved with single $T$. lutea $(7.8 \mu \mathrm{m} / \mathrm{d})$. Larvae, originated from broodstock receiving Sm or $T s$, exhibited growth compensation when fed a bispecific balanced diet (TCg). This did not occur when broodstock and larvae were fed $\mathrm{Cg}$ or $\mathrm{T}$, for which single or mixed diets led to similar larval growth. Furthermore, survival was high $(>90 \%)$ regardless of microalgal diet, except for larvae fed from broodstock to pre-settlement $T(53 \%)$ or $T s(2 \%)$. There were significant differences in 20:5 (n-3) and 22: 6 (n-3) contents in polar and neutral fractions of $O$. edulis expelled larvae dependent on broodstock diet, as well as throughout larval development, but no clear trend was apparent when comparing fatty acid (FA) relative composition of both fractions of $O$. edulis larvae fed different diets at release or prior to settlement. In contrast, such correlation occurred when FA was expressed in absolute content but exclusively for larvae-fed single diets and was particularly noticeable between 22: 6 (n-3) and growth and survival. In the present work, broodstock nutritional deficiencies have been revealed in 0 . edulis progeny, compensated thereafter by feeding the larvae a mixed diet, and in this balanced condition, no obvious relation with larval development indicators was found with main fatty acid contents.
\end{abstract}

Keywords : broodstock conditioning, diet, larval development, Ostrea edulis 


\section{Introduction}

Broodstock conditioning is an important step in the molluscan hatchery process. Indeed, conditioning allows the extension of the reproductive period (Helm, Bourne \& Lovatelli, 2004) and leads generally to better gamete quality (Utting \& Millican, 1997). The importance of temperature in molluscan reproduction has been thoroughly described (e.g. Mann, 1979; Fabioux, Huvet, Le Souchu, Le Pennec \& Pouvreau, 2005; Maneiro, Silva, Pazos, Sánchez \& Pérez-Parallé, 2017a), but the role of nutrition in quantitative aspects of reproduction is being recognized increasingly (e.g. EnriquezDiaz, Pouvreau, Chavez-Villalba \& Le Pennec, 2009). In O. edulis, a 6\% daily ration has been shown to be highly effective for broodstock conditioning (Utting, 1993), and the importance of food quality based on different microalgal diets was pointed out by Millican and Helm (1994). Since that pioneering work, only a few dedicated studies have been carried out (e.g. Berntsson, Jonsson, Wängberg \& Carlsson. 1998; Maneiro, Pérez-Parallé, Silva, Sánchez \& Pazos, 2017b). Indeed research on O. edulis reproduction was shelved following Marteilia refringens and Bonamia ostreae disease outbreaks from 1970-1980 that caused a rapid decline in the flat oyster industry in France (Buestel, Ropert, Prou \& Goulletquer, 2009) and throughout Europe (Laing, Walker \& Areal, 2005; Bromley, McGonigle, Ashton \& Roberts, 2016). However, $O$. edulis remains an emblematic species in Brittany (North West of France), with an annual production of 1000 - 1500 tons (Robert, Sanchez, Pérez-Parallé, Ponis, Kamermans \& O’Mahoney, 2013). This interest increased quite recently because of

high oyster C. gigas juvenile mortalities (e.g. Petton, Pernet, Robert \& Boudry, 2013; Azema, Lamy, Boudry, Renault, Travers \& Degremont, 2017). Accordingly, we revisited flat oyster feeding requirements during conditioning and showed that, based 
upon ecophysiological and biochemical studies, some microalgae more effectively supported gametogenesis (González-Araya, Quéau, Quéré, Moal \& Robert, 2011; González-Araya, Lebrun, Quéré \& Robert, 2012a). Specificall, Chaetoceros neogracile and Skeletonema marinoi were ingested and assimilated well; whereas, Tetraselmis suecica was poorly absorbed with no significant enrichment in the main fatty acids and sterols in any tissue at the end of a 6 week feeding experiment. Tisochrysis lutea was found to be moderately effective as a diet (assimilation efficiency $=20 \%$ ) and a highly efficient source of essential lipids (e.g 22:5 (n-6)) (González-Araya et al., 2011). On the other hand, larval development has shown to be related to the type of food delivered during conditioning (Berntsson et al., 1997), with apparent but inconsistent compensation when larvae are fed a mixed diet (González-Araya et al., 2012b). Moreover, several studies (Helm, Holland, Utting \& East, 1991, Jonsson, Berntsson, André \& Wängberg, 1999) have suggested that some PUFAs are essential for survival and development of $O$. edulis larvae as demonstrated for C. gigas larvae (da Costa, Robert, Quéré, Wikfors \& Soudant, 2015).

Such interactions between broodstock diets and subsequent larval development were addressed in the present work by feeding $O$. edulis larvae the same single diets as broodstock and comparing larval performance to larvae fed a bispecific diet used as reference for oyster development in our laboratory (Rico Villa, Pouvreau \& Robert, 2009; Petton, Le Souchu, Mingant \& Robert, 2009). We hypothesised that broodstock nutritional deficiencies could be revealed and compensated at larval development by feeding the larvae a mixed, balanced diet. 


\section{Materials and methods}

Broodstock conditioning and larval rearing

A total of 36018 -month-old flat oysters ( $\approx 5 \mathrm{~cm}$ length and $0.5 \mathrm{~g}$ flesh dry weight) originating from Brittany (Bay of Cancale, France) were distributed homogeneously in translucent, 50 -L tanks (30 oysters per tank for an equivalent biomass: $1 \mathrm{~kg}$ total weight and $16 \mathrm{~g}$ dry flesh weight). Triplicate tanks were set up for each of the four single species diets tested. Seawater was maintained at $19{ }^{\circ} \mathrm{C}$ in a flow-through system at a flow rate of $12 \mathrm{~L} \mathrm{~h}^{-1}$, and the oysters were fed continuously by means of a peristaltic pump, at $900 \mu \mathrm{m}^{3} \mu \mathrm{L}^{-1}$ per feeding condition to limit pseudofaeces deposition (González-Araya et al., 2011). Seawater at ambient salinity $\left(34 \mathrm{~g} \mathrm{~L}^{-1}\right)$ was filtered on 1$\mu \mathrm{m}$ polypropylene filter media following UV treatment. Four microalgal diets were delivered during broodstock conditioning (40 days): Tisochrysis lutea (formely named Isochrysis affinis galbana or T-Iso: CCAP 927/14 = T), Chaetoceros neogracile (UTEX LB2658 = Cg), Skeletonema marinoi $($ CCAP 66/4 = Sm), or Tetraselmis suecica (CCAP 1077/3= Ts). Microalgal size, growth, biochemical profiles, and other characteristics have been already detailed in exponential and stationary phases (Robert et al., 2004; González-Araya et al., 2011). Accordingly, only a brief outline will be given here with total fatty acid compositions, expressed as relative and absolute contents (Table 1). From each treatment, released larvae were distributed in 5-L, translucent, methacrylate cylinders and reared in flow-through conditions with UV treatment (González-Araya et al., 2012 b). Larval expulsion was asynchronous, but broodstock fed different diets released first batches of larvae within 10 days meaning that they were not reared simultaneously but in a closed window-time (April). Larvae at a density of $5 \mathrm{~mL}^{-1}$ were 
distributed, in triplicate for each larval diet, in seawater at $22{ }^{\circ} \mathrm{C}$ and $34 \mathrm{~g} \mathrm{~L}^{-1}$ salinity. Larvae were fed continuously the same single-species, microalgal diets as delivered to broodstock at $1,500 \mu \mathrm{m}^{3} \mu \mathrm{L}^{-1}$ equivalent $T$. lutea volume $(\approx 40$ cells $)$ or the mixed diet T. lutea plus $C$. neogracile (TCg: v/v), which has been shown to be an effective bispecific diet for Crassostrea gigas larvae (Rico-Villa, Le Coz, Mingant \& Robert, 2006; Ben Kheder, Quéré, Moal \& Robert, 2010). Each broodstock diet was split into treatments with two larval diets, i.e., 8 different larval conditions were assessed: BTLT, $\mathbf{B} T \mathbf{L} T C g, \mathbf{B} C g \mathbf{L} C g, \mathbf{B} C g \mathbf{L} T C g, \mathbf{B} S m \mathbf{L} S m, \mathbf{B} S m \mathbf{L} T C g, \mathbf{B} T s \mathbf{L} T s$, and $\mathbf{B} T s \mathbf{L} T C g$. Thus, the designation BTLT means that broodstock $(\mathbf{B})$ was fed T. lutea $(T)$ and larvae $(\mathbf{L})$ expelled from them were also fed T. lutea; whereas, $\mathbf{B} \operatorname{SmLTCg}$ means that broodstock was fed $S$. marinoi and larvae expelled from them were fed $T$. lutea plus $C$. neogracile $(T C g)$.

Larval length and survival were quantified on days 3, 6, 9 and 11 under the light microscope by use of an image analysis technique (WinImager 2.0 and Imaq Vision Builder 6.0 software for image capture and treatment, respectively) and direct counting of empty shells for dead larvae estimation. The number of pediveligers ready to set (competent larvae possessing an eyespot) was estimated at the end of the experiment, on day 11.

\section{Biochemical procedures}

About 10000 larvae were sampled, on each larval treatment, at 0 (released larvae) and 11 days (end of larval rearing); the samples were collected by filtration on pre-ignited (at $450^{\circ} \mathrm{C}$ ) $\mathrm{GF} / \mathrm{D}$ filter pads ( $3 \mu \mathrm{m}$ porosity). For lipid extraction, the filter pads were placed separately in tubes containing a mixture of chloroform-methanol $(2: 1, \mathrm{v} / \mathrm{v})$ with 
$0.01 \mathrm{wt} \%$ butylated hydroxytoluene (BHT) as antioxidant, closed under nitrogen, shaken and frozen at $-20^{\circ} \mathrm{C}$.

An aliquot of the sample (chloroform-methanol mixture) was evaporated to dryness, with a known amount of 23:0 fatty acid (as internal standard) and lipids were recovered with three washings of $500 \mu \mathrm{l}$ each of $\mathrm{CHCl}_{3}-\mathrm{MeOH}(98: 2$, v/v). This was placed on top of silica gel microcolum (30 x 5 mm ID, Kieselgel, 70-230 mesh (Merk), previously heated to $450^{\circ} \mathrm{C}$ and deactivated with $5 \%$ water (Marty, Delaunay, Moal \& Samain, 1992). The neutral lipids were eluted with $10 \mathrm{ml}$ of $\mathrm{CHCl}_{3}-\mathrm{MeOH}(98: 2)$ and the polar lipids were recovered with $10 \mathrm{ml}$ of $\mathrm{MeOH}$. The neutral and polar fractions were taken for methylation and analysis by chromatography.

\section{Statistical procedures}

Analysis of variance (ANOVA) was used to test for treatment effects. Statistical analyses were performed using STATISTICA software (version 8.0). Significant differences were detected between the means at the 5\% threshold and a posteriori multiple comparison test between the means (Tukeys' test), after transformation of percentage data by the function [arcsin (racine $\mathrm{x}$ i/100)].

\section{Results}

\section{Larval growth}

The size of expelled larvae ranged from $172 \mu \mathrm{m}( \pm 2.1)$ to $179 \mu \mathrm{m}( \pm 2.7)$ with no significant difference when oysters were fed either diatoms or T. lutea. In contrast, 
newly-released larvae were significantly smaller $(\mathrm{p}<0.01)$ when broodstock were fed $T$. suecica $(165 \mu \mathrm{m} \pm 3.5)$.

Larvae originating from broodstock fed S. marinoi and fed a similar diet had lower growth (Fig. 1A), with a daily length increment of $\approx 5.5 \mu \mathrm{m} \mathrm{d}^{-1}$ (Fig. 2A). The supply of a mixed larval diet $(T C g)$ improved growth somewhat (Fig. 1B), with daily growth of $6.0 \mu \mathrm{m} \mathrm{d}^{-1}$ (Fig. 2A). Similarly larvae fed $T$. suecica as broodstock exhibited relatively good growth until day 7 (Fig. 1A), with a daily length increment of $6 \mu \mathrm{m} \mathrm{d}^{-1}$ (Fig. 2A); whereas, a noticeable improvement in larval development was recorded when these larvae were fed mixed diet $T C g$ (Fig. 1B), leading to a daily length increment of $\approx 8.0$ $\mu \mathrm{m} \mathrm{d}^{-1}$ (Fig. 2A). Larvae originated from broodstock fed T. lutea or C. neogracile exhibited the highest growth when fed broodstock-based diets (Fig. 1A), with 7.5 and $7.1 \mu \mathrm{m} \mathrm{d}^{-1}$ daily length increments, respectively (Fig. 2A), but no significant differences ( $>0.05)$ were found when larvae were fed mixed diets (Fig 1B), with daily length increments of 8.3 and $7.8 \mu \mathrm{m} \mathrm{d}^{-1}$ respectively (Fig. 2A).

\section{Larval survival}

Under most experimental conditions, larval survival was high, $>90 \%$ on day 11 , except when larvae and broodstock were fed single T. lutea (53\%) or T. suecica (2\% : Fig. 2B). For this last condition, mortalities took place progressively with moderate larval survival on day $3(40 \%)$ increasing to $(100 \%)$ on day 7 ; whereas, larvae fed T. lutea exhibited low mortalities until day 11 when mortality was sudden. 
No clear relationship between diet and competence to metamorphosis wa found (Fig. 2C). At the end of the larval rearing period (day 11), $25 \%$ of pediveligers were eyed when larvae originating from broodstock fed $T$ or $T s$, were fed $T C g$. However, eyed larvae accounted for $46-50 \%$ of the total in larvae originating from broodstock fed $C$. neogracile or S. marinoi, respectively (Fig. 2C).

\section{Biochemical composition}

The biochemical contents of the four microalgae used here as food f230or O. edulis have been described in a previous work reporting on broodstock conditioning (González-Araya et al., 2010), so only a brief outline will be given here. With $10.2 \%$ of total fatty acids, T. lutea was rich in 22:6 (n-3) (DHA) but very poor (0.33\%) in 20:5(n3) (EPA). With $\approx 22-23 \%$ of total fatty acids, C. neogracile and S. marinoï were rich in 20:5 (n-3) but relatively poor (1.1\%) to moderate (4.4\%) in $22: 6(n-3)$. With $30.8 \% T$. suecica was rich in 16:0 (vs 6.7-11.1\% for the other species). In contrast, with only $0.23 \%$ T. suecica almost lacked 22:6 (n-3); whereas, it contained moderate amount $(4.4 \%)$ of $20: 5(n-3)$.

16:0, 20:5 (n-3) and 22:6 (n-3) were the dominant fatty acids in O. edulis larvae with values varying from $6.7 \%$ to $21.6 \%$ in polar fraction (Table 2) and $3.3 \%$ to $23.3 \%$ in neutral fraction (Table 4) regardless larval stage or diet.

At release, a similar relative amount of 16:0 in the polar fraction was recorded in larvae regardless broodstock diet, with values fluctuating from $12.3 \%$ to $13.7 \%$ (Table 2 ). In contrast, when expressed in absolute content, the larvae originating from broodstock fed 
S. marinoi exhibited a significantly lower concentration $(\mathrm{p}<0.05)$ with $0.7 \mathrm{ng} \mathrm{larva}^{-1} v s$ 1.1-1.6 $\mathrm{ng} \operatorname{larva}^{-1}$ for the other diets (Table 3). Similarly, significant differences $(p<0.05)$ in $16: 0$ relative content were found in neutral fraction of expelled larvae, with values varying from $14 \%$ to $23.3 \%$; accordingly, broodstock diet interfered with initial biochemical composition of larval storage (Table 4). Such effects were also found when fatty acid composition was expressed in absolute content with, however, no differences $(\mathrm{p}<0.05)$ in initial larval biochemical content when broodstock were fed T. lutea or $T$. suecica (Table 5). Despite initial stores, no apparent enrichment in 16:0 occurred during O. edulis larval development because 16:0 relative content remained quite similar (p> 0.05), with values varying from 10.6 to $15.9 \%$ in larval polar fraction (Table 2). In contrast, there was an overall decrease in this FA in the larval neutral fraction throughout larval development regardless of diet (Table 4).

There were significant differences $(\mathrm{p}<0.05)$ in 20:5 (n-3) relative and absolute contents within $O$. edulis expelled larvae dependent upon broodstock diet, with values fluctuating from $6.7 \%$ to $19.1 \%$ and from 0.7 to $2.4 \mathrm{ng} \operatorname{larva}^{-1}$ in the polar fraction (Tables 2,3 ) and from $3.3 \%$ to $15.8 \%$ and 3.5 to $25.1 \mathrm{ng} \operatorname{larva}^{-1}$ in the neutral fraction (Tables 4, 5). Thus, larvae originating from broodstock fed C. neogracile or S. marinoi exhibited the highest EPA concentration in both fractions (polar: 19.1\% and $17.1 \%$ (Table 2); neutral: $15.8 \%$ and $14.7 \%$ (Table 4) respectively). When expressed as absolute FA content, this was the case only for $C$. neogracile, with $2.4 \mathrm{ng} \mathrm{larva}^{-1}$ and $25.1 \mathrm{ng}$ larva ${ }^{-1}$ in the polar and neutral fractions, respectively (Tables 3, 5). In contrast, progeny originating from broodstock fed $T$. lutea showed the lowest relative contents $(6.7 \%$ and $3.3 \%$, respectively, in polar and neutral fractions: Tables 2, 4); a finding confirmed when FA composition was expressed as absolute content for the neutral fraction (Table 5) but not for the polar fraction (Table 3). Surprisingly the initial content 
of expelled larvae originated form broodstock fed $T$. suecica exhibited relatively high percentage content of 20:5 (n-3) in both fractions (15.2 and $11.9 \%$ respectively in polar and neutral fractions: Tables 2, 4), which was confirmed for the absolute content (1.2 ng $\operatorname{larva}^{-1}$ and $9.3 \mathrm{ng} \mathrm{larva}^{-1}$ respectively in polar and neutral fractions: Tables 3, 5). In both fractions, 20:5 (n-3) concentration increased significantly $(\mathrm{p}<0.05)$ in larvae fed T. lutea that had originated from broodstock also fed T. lutea $(15.9 \%$ vs $6.7 \%$ and $18.1 \%$ vs $3.3 \%$, respectively in polar and neutral fractions: Tables 2,4$)$. This enhancement was more acute when FA composition was expressed in absolute content (13.3 vs $0.7 \mathrm{ng}$ $\operatorname{larva}^{-1}$ and 333.5 vs $3.5 \mathrm{ng}$ larva $^{-1}$ respectively in polar and neutral fractions: Tables 3, 5) A similar finding was obtained with broodstock and larvae solely fed $C$. neogracile, with EPA larval relative content increasing to $25.7 \%$ vs $19.1 \%$ and $24.2 \%$ vs $15.8 \%$, respectively, in polar and neutral fractions: Tables 2, 4); an acute enhancement in the neutral fraction was also found when expressed as absolute FA content (235.8 $\mathrm{ng}$ larva $^{-1}$ vs $25.1 \mathrm{ng}$ larva $^{-1}$ (Table 5).

With $\mathrm{R}^{2}=0.10$, a non-significant $(\mathrm{p}>0.05)$ linear relationship between mean daily growth and EPA relative content was found, regardless of larval diet. In contrast, when expressed in absolute FA content, a relationship with growth occurred for larvae fed single diets $\left(R^{2}=0.51:\right.$ Fig. $\left.3 A\right)$ but did not exist for larvae fed mixed diets $\left(R^{2}=0.03\right.$ : Table 6 and Fig. 3C). Similar, general trends were confirmed for the other larval development descriptors (e.g., competence: Table 6 and Fig. 3 B, D).

There were significant differences $(\mathrm{p}<0.05)$ in 22:6 (n-3) content of $O$. edulis expelled larvae between broodstock diet treatments, with values fluctuating from $12.5 \%$ to $21.6 \%$ in the polar fraction (Table 2) and from $8.0 \%$ to $15.5 \%$ in the neutral fraction (Table 4), which was confirmed when FA composition was expressed as absolute content for the neutral fraction (Table 5) but not for the polar fraction (Table 3). Larvae 
originating from broodstock fed $T$. lutea or $T$. suecica exhibited the highest DHA concentrations in both fractions (polar: $21.6 \%$ and 20.2\% (Table 2); neutral: $15.5 \%$ and 13.6\% (Table 4) respectively). However such a relationship was only confirmed for $T$. lutea when biochemical composition was expressed in absolute content in the neutral fraction (Table 5). With the exception of larvae expelled from broodstock fed $S$. marinoi, 22:6 (n-3) concentration decreased significantly $(\mathrm{p}<0.05)$ in both fractions throughout larval development, regardless of larval diet (Tables 2, 4); whereas, no clear trend could be established when FA composition of larvae was expressed as absolute content (Tables 3, 5).

With $\mathrm{R}^{2}=0.09$, a non-significant $(\mathrm{p}>0.05)$ linear relation between mean daily growth and DHA relative content was found. In contrast, when expressed in absolute FA content, a significant relationship with growth was found for larvae fed single diets $\left(\mathrm{R}^{2}\right.$ $=0.82$ : Fig. 3A), but not for larvae fed mixed diets $\left(R^{2}=0.03\right.$ : Table 6 and Fig. 3C). A similar, general trend was confirmed for the other larval development descriptors and specifically for survival $\left(\mathrm{R}^{2}=0.97\right.$ vs 0.19 : Table 6).

Diets had lower influence on 20:4(n-6) (ARA) content of expelled larvae, in both fractions (polar: $3.7 \%$ to $4.7 \%$ (Table 2); neutral: $1.0 \%$ to $2.4 \%$ (Table 4 ), ) as well as throughout larval development during which significant $(\mathrm{p}<0.05)$ decreases occurred for larvae fed C. neogracile or T. suecica (Tables 2,4). This trend was not confirmed when FA composition was expressed in absolute content (Tables 3, 5).

With $\mathrm{R}^{2}=0.02$, no linear relationship between mean daily growth and DHA relative content was found. In contrast, when expressed as absolute FA content, a relationship with growth was found for larvae fed single diets $\left(\mathrm{R}^{2}=0.74:\right.$ Fig. $\left.3 \mathrm{~A}\right)$, but did not exist for larvae fed mixed diets $\left(\mathrm{R}^{2}=0.00\right.$ : Table 6 and Fig. 3C). Similar, general trends were 
confirmed for the other larval development descriptors, and for survival $\left(\mathrm{R}^{2}=0.82 \mathrm{vs}\right.$ 0.15 : Table 6).

\section{Discussion}

Live microalgae are essential for successful larval performance, especially bivalve metamorphosis that relies on energy reserves stored during two developmental stages (Labarta, Fernandez-Reiriz \& Perez-Camacho, 1999). The first stage corresponds to embryonic development wherein endogenous reserves are provided by the egg (Bayne, 1973), and the second stage prior to metamorphosis, which depends on reserves stored during all of larval life. The latest depends on the food value of algal diets supplied to growing larvae combined with endogenous reserves (Whyte, Bourne \& Ginther, 1990). The nutritional value of different live microalgae is determined by ingestibility (cell size/shape), digestibility, and nutrient content (Brown, Jeffrey, Vilkman \& Dunstan, 1997). The nutritional role in bivalve nutrition has been emphasized for essential polyunsaturated fatty acids (PUFAs), especially the n-3 fatty acids eicosapentaenoic (EPA, 20:5 n-3) and docosahexaenoic acid (DHA, 22:6 n-3) necessary for successful growth and development (Langdon \& Waldock, 1981; Thompson, Guo \& Harrison, 1996; Martinez-Fernandez, Acosta-Salmon \& Southgate, 2006). These lipids play important structural roles in regulating cell-membrane fluidity and other cellular functions (Hazel, Williams, Livermore, Mozingo, 1991; Hall, Parrish \& Thompson, 2002). In general, bivalves have limited or no ability to synthesize PUFAs or to elongate shorter-chained compounds (da Costa et al., 2016) but require these for growth and development (Waldock \& Holland, 1984; Whyte, Bourne, \& Hodgson, 1989; Chu 
\& Greaves, 1991; Marty, Delaunay, Moal \& Samain, 1992; Delaunay, Marty, Moal \& Samain, 1993). Although the effects of nutrition on larval growth and survival have been studied extensively in a wide range of molluscs (see review of Marshall, McKinley \& Pearce, 2012), the effects of food on broodstock and subsequent larval development performances have received less attention.

In the present work, initial larval size was related to diet quality expressed as the type of microalgae delivered during broodstock conditioning. Thus, when larval growth relies on energetic reserves stored during embryogenesis, larvae released from broodstock fed single $T$. suecica were probably poorly enriched compared to larvae from broodstock fed other microalgal diets. Such larval size variability upon release (from 178 to 186 $\mu \mathrm{m})$, related to broodstock diets, have been already reported (Berntsson et al., 1997) with, however, no statistical differences between treatments. This result may have been attributable to the richness of natural seston in incoming seawater. Indeed in the reported experiment, unfed oysters released larvae of similar size to those expelled by fed oysters. In contrast, in our experiment seawater was $1-\mu \mathrm{m}$ filtered and UV-treated, meaning that there was no apparent bias in our feeding conditions. However, no clear trend could be detectable in fatty acid composition of newly released larvae originated from broodstock fed $T$. suecica, when analysing specific fatty acids such as DHA, with initial content as high as that recorded in progeny originated for broodstock fed T. lutea (20 vs $22 \%$ and 1.6 vs $2.2 \mathrm{ng} \mathrm{larva}^{-1}$ for relative and absolute contents respectively). A transfer from original oyster reserve (stored before conditioning) might explain that compensation because $T$. suecica lacked DHA (0.23\%) and has been shown to be poorly assimilated in gonad and other tissues during $O$. edulis broodstock conditioning (González-Araya et al., 2011). The situation was similar when considering FA ratios as $(n-3) /(n-6), 22: 6 / 20: 5,22: 5 / 20: 4$ that did not reveal any outliers nor explanatory values. 
No differences in larval growth were found when larvae were fed single or mixed diets, originated from broodstock previously fed $T$. lutea or $C$. neogracile, with no clear trend in main relative fatty acids composition. Moreover, when fed T. lutea, O. edulis larval growth was quite similar to that reported with Isochrysis galbana, a closely-related haptophyte $\left(9 \mu \mathrm{m} \mathrm{d}^{-1}\right.$ : Ferreiro, Perez-Camacho, Labarta, Beiras, Planas \& FernandezReiriz, 1990). In contrast, larvae originating from broodstock fed $S$. marinoi showed lower growth regardless of larval diet, single or mixed. In this case, relative content of 20:5 (n-3) remained constant from release to metamorphosis except when larvae were fed single $S$. marinoi but decreased significantly, in both polar and neutral fractions, when mixed larval diet $T C g$ was delivered. This result contrasts with a previous work (Enright, Newkirk, Craigie \& Castell, 1986) that classified S. costatum (named now $S$. marinoi) as the second highest-ranked diatom for $O$. edulis growth (juvenile). Such apparent contradiction can be explained by the size of this microalga and the stage of bivalve development at which this diatom was delivered. Indeed, $S$. marinoi is a colonial diatom formed of spherical to cylindrical cells joined in chains. Colonies can be longer than $60 \mu \mathrm{m}$ (Sauriau \& Baud, 1994), but in 300-L batch cultures in Argenton, colonies are usually composed of 2 to 4 cells, and the chains rarely exceed 10-15 $\mu \mathrm{m}$ in length (Robert, unpublished data). Accordingly, this phytoplankton size is more appropriate for older bivalve stages than larvae (Robert \& Gérard, 1999). When fed $S$. marinoi, O. edulis larval performance was, nevertheless, more-closely in agreement with that reported by Ferreiro et al. (1990), who classified this diatom as the worst tested microalga, supporting $O$. edulis larval growth of only $0.4 \mu \mathrm{m} \mathrm{d}^{-1}$ (12- fold lower than in the present work). On the other hand, larvae fed the mixed diet and originating from broodstock fed $T$. suecica showed surprisingly similar growth from day 7 as larvae released by broodstock previously fed $T$. lutea or C. neogracile. Larvae fed solely $T$. 
suecica exhibited lower growth, reaching however $6 \mu \mathrm{m} \mathrm{d}^{-1}\left(v s 7.3 \mu \mathrm{m} \mathrm{d}^{-1}\right.$ for the mixed larval diet). This relatively good larval growth was, however, counterbalanced by very low larval survival (2\%) that did not allow biochemical analysis. These results contrast with those reported by Berntsson et al. (1998) for broodstock fed single T. suecica that induced higher larval growth $\left(4.5 \mu \mathrm{m} \mathrm{d}^{-1}\right)$ than larvae originated from broodstock fed $T$. suecica plus C. calcitrans $\left(1.7 \mu \mathrm{m} \mathrm{d}^{-1}\right)$.

No relationships were found between larval and growth main fatty acids when they were expressed in relative content. In contrast, a positive correlation was found with DHA absolute content and growth for single larval diets, regardless of microalgae species; whereas such correlation was not obvious for mixed larval diets. A similar correlation with DHA relative content of released O. edulis larvae and larval growth has been already reported (Berntsson et al., 1997) and should explained 50\% of the variation in growth rate among broodstock. In contrast these authors did not find any correlation between EPA and growth as pointed out in this present work.

Generally, in the present work larval survival was high ( $\geq 90 \%)$, except for larvae fed $T$. suecica and originating from broodstock also fed $T$. suecica $(2 \%)$. Our results partially agree with those of Fereiro et al (1990) who reported large survival fluctuations between $O$. edulis larval batches, fed $T$. suecica, from 0 to $100 \%$, with, relatively good growth though $\left(8.7 \mu \mathrm{m} \mathrm{d}^{-1}\right)$. When broodstock were fed $T$. suecica and released larvae were fed our mixed diet, larval survival was similar to that reported by Berntsson et al. (1998), with survival $\geq 90 \%$. When continuously fed single $T$. suecica from broodstock through the entire larval life, deficiencies might occur, leading to high larval mortality. We noted a similar trend for T. lutea with, however, higher survival (53\%) but no clear relation with main relative fatty acid content was established. Lastly, competence to metamorphose did not reveal clearly the influence of larval diet when comparing the 
effects of each microalgae. However positive correlations were found with EPA absolute contents and eyed larval percentage, with single larval diets regardless of the species; such a correlation was not significant for mixed larval diets. Larvae continuously fed S. marinoi, from broodstock to pre-settlement, exhibited a low level of competence, which is in agreement with corresponding data on growth. A similar trend occurred with larvae fed single $T$. suecica, which is in agreement with data on survival. Moreover, except for $T$. lutea, mixed diets $\left(T C_{g}\right)$ led to higher larval competence, which is partially in agreement with our previous work (González-Araya et al., 2012).

When analysing the overall $O$. edulis development performance, larvae fed single $T$. lutea from broodstock to pre-settlement exhibited deficiencies which were expressed in $50 \%$ mortality. Larvae fed S. marinoi showed lower growth and competence clearly related to cell size, which was unlikely to have been consumed efficiently this early stage. Lastly, when larvae were fed T. suecica, severe nutritional deficiencies occurred, leading to the death of the entire larval population. Regardless of broodstock feeding, however, these potential deficits seem to be mitigated when expelled larvae are fed $T C_{g}$, which globally led to better larval performances.

\section{Conclusion}

The present work confirmed that some broodstock nutritional deficiencies, originating from broodstock conditioning, could be compensated at early stage development when larvae are fed a mixed, balanced diet. Although larvae fed T. suecica from broodstock to pre-settlement exhibited high mortalities and moderate growth, those receiving a bispecific diet displayed good larval performance. Such partial improvement also 
occurred with $T$ lutea for larval survival. However, to accurately understand the relationships between biochemical transfers from diets to broodstock, from broodstock to initial larvae, and from diets to larvae in development, a more complex experimental design should be carried out. It should be based on single, efficient diets characterized by different fatty acids and should include a starved control to specify the contributions of broodstock and larval reserves. Moreover it would also include metamorphosis determination, because, in contrast with $C$. gigas, $O$ edulis larval growth is insufficient to discriminate the effects of diets. Some evidence was found, as mortality data revealed severe deficiencies that could not be related to biochemical composition because insufficient live larvae remained for analysis. Such an experiment will be reported in a forthcoming paper.

\section{Acknowledgments}

This work could not have been completed without the technical support of the team at the Argenton Ifremer station -C. Mingant, I. Quéau and L. Lebrun- and the LPI analytical biochemical platform -C. Quéré- all of whom we wish to thank. A great thank to G. Wikfors from Milford laboratory for improving English. We are also grateful to the Universidad de Los Lagos (MECESUP-ULA 03/02), which contributed to the partial funding of a PhD grant for the second author. This work was carried out during the SETTLE project and was partially funded by FP7/2007-2013 under agreement no. 222043. 


\section{References}

Azema P., Lamy J.B., Boudry P., Renault T., Travers, M.A., Degremont L. (2017) Genetic parameters of resistance to Vibrio aestuarianus, and OsHV-1 infections in the Pacific oyster, Crassostrea gigas, at three different life stages. Genetic Selection evolution 49. https://doi.org/10.1186/s12711-017-0297-2

Bayne B.L. (1973). Aspects of the metabolism of Mytilus edulis during starvation. Netherland Journal of Sea Research 7, 399-441.

Ben Kheder R., Quéré, C., Moal J., Robert R. (2010). Effect of nutrition on C. gigas larval development and the evolution of physiological indices. Part A: quantitative and qualitative diet effects. Aquaculture 305, 165-173. https://doi.org/10.1016/j.aquaculture.2010.04.022

Berntsson K.M., Jonsson P.R., Wängberg S.Å., Carlsson A.S. (1998). Effects of broodstock diets on fatty acid composition, survival and growth rates in larvae of the European flat oyster, Ostrea edulis. Aquaculture 154, 139-153. https://doi.org/10.1016/S0044-8486(97)00041-0.

Bromley C., McGonigle C., Ashton E.C., Roberts D. (2016). Bad moves: Pros and cons of moving oysters - A case study of global translocations of Ostrea edulis Linnaeus, 1758 (Mollusca: Bivalvia). Ocean \& Coastal Management 122, 103-115. http://dx.doi.org/10.1016/j.ocecoaman.2015.12.012

Brown M.R., Jeffrey S.W., Vilkman J.K., Dunstan, G.A. (1997). Nutritional properties of microalgae for mariculture. Aquaculture 151, 315-331. https://doi.org/10.1016/S0044-8486(96)01501-3 
Buestel D., Ropert M., Prou J., Goulletquer P. (2009). History, status, and future of oyster culture in France. Journal of Shellfish Research 28, 813-820. https://doi.org/10.2983/035.028.0410

Chu F.L.E., Greaves J. (1991). Metabolism of palmitic linoleic and linolenic acids in adult oysters, Crassostrea virginica. Marine Biology 110, 229-236. https://doi.org/10.1007/BF01313708

Delaunay F., Marty Y., Moal J., Samain J.F. (1993). The effect of monospecific algal diets on growth and fatty acid composition of Pecten maximus (L.) larvae ; Journal of Experimental Marine Biology and Ecology 173, 163-179. https://doi.org/10.1016/0022-0981(93)90051-O

da Costa F., Robert R., Quéré C., Wikfors G., Soudant P. (2015). Essential fatty acid assimilation and synthesis in larvae of the bivalve Crassostrea gigas. Lipids 50, 503511. https://doi.org/10.1007/s11745-015-4006-Z

Enright C.T., Newkirk G.F., Craigie J.S., Castell J.D. (1986). Evaluation of phytoplankton as diets for juvenile Ostrea edulis L. Journal of Experimental Marine Biology and Ecology 96, 1-13. https://doi.org/10.1016/0022-0981(86)90009-2

Enriquez-Diaz M., Pouvreau S., Chavez-Villalba J., Le Pennec M. (2009). Gametogenesis, reproductive investment, and spawning behavior of the Pacific giant oyster Crassostrea gigas: evidence of an environment-dependent strategy. Aquaculture International 17, 491-506. https://doi.org/10.1007/s10499-008-9219-1

Fabioux C., Huvet A., Le Souchu P., Le Pennec M., Pouvreau S. (2005). Temperature and photoperiod drive Crassostrea gigas reproductive internal clock. Aquaculture 250, 458-470. https://doi.org/10.1016/j.aquaculture.2005.02.038

Ferreiro M.J., Perez-Camacho A., Labarta U., Beiras R., Planas M., Fernandez-Reiriz M.J. (1990). Changes in the biochemical composition of Ostrea edulis larvae fed on 
different food regimes. Marine Biology 106, 395-401. https://doi.org/10.1007/BF01344318

González-Araya R., Quéau I., Quéré C., Moal J., Robert R. (2011). A physiological and biochemical approach to selecting the ideal diet for Ostrea edulis (L.) broodstock conditioning (Part A). Aquaculture Research 42, 710-726. 10.1111/j.1365$\underline{2109.2010 .02731 . x}$

González-Araya R., Lebrun L., Quéré C., Robert R. (2012a). The selection of the ideal diet for Ostrea edulis (L.) broodstock conditioning (part B). Aquaculture 362-363, 55-66. https://doi.org/10.1016/j.aquaculture.2012.06.029

González Araya R., Petton B., Mingant C., Robert R. (2012b). Influence of diet assemblage on Ostrea edulis broodstock conditioning and subsequent larval development. Aquaculture 364-365, 272-280. http://dx.doi.org/10.1016/j.aquaculture.2012.08.036

Hall, J.M., Parrish, C.C., Thompson, R?J., 2002. Eicosapentaeonic acid regulates scallop (Placopecten magellanicus) membrane fluidity in response to cold. Biology Bulletin 202, 201-203. https://doi.org/10.2307/1543469

Hazel J.R., Williams E.E., Livermore R., Mozingo N. (1991). Thermal adaption in biological membranes: functional significance of changes in phospholipid molecular species composition. Lipids 26, 277-282. https://doi.org/10.1007/BF02537137

Helm M.M., Holland D.L., Utting S.D., East J. (1991). Fatty acid composition of early non-feeding larvae of the European flat oyster, Ostrea edulis L. Journal of Marine Biological Association UK 71, 691-705.https://doi.org/10.1017/S0025315400053248

Helm M.M., Bourne N., Lovatelli A. (2004). Hatchery culture of bivalves, a practical manual. FAO Fisheries Technical Paper, No.471 FAO, Rome, Italy, 177pp. 
Jonsson P. R., Berntsson K.M., André C., Wängberg S.-Å. (1999). Larval growth and settlement of the European oyster (Ostrea edulis) as a function of food quality measured as fatty acid composition. Marine Biology 143, 559-570. https://doi.org/10.1007/s002270050571

Labarta U., Fernandez-Reiriz M.J., Perez-Camacho A. (1999). Energy, biochemical substrates and growth in the larval development, metamorphosis and postlarvae of Ostrea edulis. Journal of Experimental Marine Biology and Ecology 238, 225-242. https://doi.org/10.1016/S0022-0981(98)00171-3

Laing I., Walker P., Areal F. (2005). A feasibility study of native oyster (Ostrea edulis) stock regeneration in the United Kingdom. CARD Project FC1016, Native oyster Stock Regeneration - A review of Biological, Technical and Economic Feasibility, $95 \mathrm{pp}$.

Langdon C.J., Waldock M.J. (1981). The effect of algal and artificial diets on the growth and fatty acid composition of Crassostrea gigas spat. Journal of Marine Biological Association UK 61, 431-448. https://doi: 10.1017/S0025315400047056

Maneiro V., Silva A., Pazos A.J., Sánchez J.L., Pérez-Parallé M.L. (2017a). Effects of temperature and photoperiod on the conditioning of the flat oyster (Ostrea edulis L.) in autumn. Aquaculture Research, 48, 4554-4562. https://doi:10.1111/are.13280

Maneiro V., Pérez-Parallé M.L., Silva A., Sánchez J.L., Pazos A.J. (2017b). Conditioning of the European flat oyster (Ostrea edulis, Linnaeus 1758): effect of food ration. Aquaculture Research, 48, 4363-4370. https://doi:10.1111/are.13259

Mann R. (1979). Some biochemical and physiological aspects of growth and gametogenesis in Crassostrea gigas and Ostrea edulis grown at sustained elevated temperatures. Journal of Marine Biological Association UK 59, 546-559. https://doi.org/10.1017/S0025315400046208 
Marshall R., Mc Kinley S., Pearce M. C. (2012). Effects of nutrition on larval growtg and survival in bivalves. Review in Aquaculture 2, 33-55. doi: https://10.1111/j.1753$\underline{5131.2010 .01022 . \mathrm{x}}$

Martinez-Fernandez, E., Acosta-Salmon H., Southgate P.C. (2006). The nutritional value of seven species of tropical microalgae for black-lip pearl oyster (Pinctada margaritifera, L) larvae. Aquaculture 257, 491-503. https://doi.org/10.1016/j.aquaculture.2006.03.022

Marty Y., Delaunay F., Moal J., Samain J.F. (1992). Changes in the fatty acid composition of Pecten maximus (L.) during larval development. Journal of Experimental Marine Biology and Ecology 163, 221-234. https://doi.org/10.1016/0022-0981(92)90051-B

Millican P.F., Helm M.M. (1994). Effects of nutrition on larvae production in the European flat oyster, Ostrea edulis. Aquaculture 123, 83-94. https://doi.org/10.1016/0044-8486(94)90121-X

Petton B., Pernet F., Robert R., Boudry P. (2013). Temperature influence on pathogen transmission and subsequent mortalities in juvenile Pacific oysters Crassostrea gigas. Aquaculture Environment Interactions 3, 257-273. $\underline{\text { https://doi.org/10.3354/aei00070 }}$

Petton B., Le Souchu P., Mingant C., Robert R. (2009). Determining hydrobiological larval rearing parameters for Crassostrea gigas in small volume flow-through containers. LARVI '09 - Fish \& shellfish larviculture symposium., 07-10 September 2009, Ghent, Belgium, Book of Abstract, Special Publication EAS, No 38, 333-334.

Rico-Villa B., Le Coz J.R., Mingant C., Robert R. (2006). Influence of phytoplankton diet mixtures on microalgae consumption, larval development and settlement of the 
Pacific oyster Crassostrea gigas (Thunberg). Aquaculture 256, 377-388. https://doi.org/10.1016/j.aquaculture.2006.02.015

Rico Villa B., Pouvreau S., Robert R. (2009). Influence of food density and temperature on ingestion, growth and settlement of Pacific oyster larvae Crassostrea gigas. Aquaculture 287, 395-401. https://doi.org/10.1016/j.aquaculture.2008.10.054

Robert R., Sanchez J.L., Pérez-Parallé L., Ponis E., Kamermans P., O’Mahoney M. (2013). A glimpse of the mollusc industry in Europe. Aquaculture Europe 38, 5-11.

Robert R., Gérard A. (1999). Bivalve hatchery technology: the current situation for the Pacific oyster Crassostrea gigas and the scallop Pecten maximus in France. Aquatic Living Resources 12, 121-130. https://doi.org/10.1016/S0990-7440(99)80021-7

Robert R., Chrétiennot-Dinet M.J., Kaas R., Martin-Jézéquel V., Moal J., Le Coz J.R., Nicolas J.L., Bernard E., Connan J.P., Le Dean L., Gourrierec G., Leroy B., Quéré C. (2004). Amélioration des productions phytoplanctoniques en écloserie de mollusques: caractérisation des microalgues fourrage, $R I D R V / R A-\mathbf{2 0 0 4 - 0 5}, 149 \mathrm{pp}$.

Sauriau P.G., Baud J.P. (1994). Artificial filament breakage of the diatom Skeletonema costatum intended for mollusk aquaculture. Aquaculture 123, 69-81. https://doi.org/10.1016/0044-8486(94)90120-1

Thompson P.A., Guo M., Harrison P.J. (1996). Nutritional value of diets that vary in fatty acid composition for larval pacific oysters (Crassostrea gigas). Aquaculture 143, 379-391. https://doi.org/10.1016/0044-8486(96)01277-X

Utting S.D. (1993). Procedures for maintenance and hatchery-conditioning of bivalve broodstocks. World Aquaculture, Technical Report, 78-82.

Utting S.D., Millican P.F. (1997). Techniques for the hatchery conditioning of bivalve broodstocks and the subsequent effect on egg quality and larval viability. Aquaculture 155, 45-54. https://doi.org/10.1016/S0044-8486(97)00108-7 
Waldock M.J., Holland D.L. (1984). Fatty acid metabolism in young oysters, Crassostrea gigas: polyunsaturated fatty acids. Lipids 19, 332-336. https://doi.org/10.1007/BF02534783

Whyte J.N.C., Bourne N., Hodgson C.A. (1989). Influence of algal diets on biochemical composition and energy reserves in Patinopecten yessoensis (Jay) larvae. Aquaculture 78, 333-347. https://doi.org/10.1016/0044-8486(89)90110-5

Whyte J.N.C., Bourne N., Ginther N.G. (1990). Biochemical and energy changes during embryogenesis in the rock scallop Crassadoma gigantea. Marine Biology 106, 239244. https://doi.org/10.1007/BF01314806 


\section{Figures}

Figure 1. Mean growth and standard deviation of $O$. edulis larvae fed different single diets: T: Tisochrysis lutea, Cg: Chaetoceros neogracile, Sm: Skeletonema marinoi and Ts: Tetraselmis suecica (A) or fed bispecific diet TCg: T. lutea $+C$. neogracile (B), from release (day 0 ) to day 11. Larvae were originated from parents fed similar single diets (T, Cg, Sm or Ts) during broodstock conditioning.
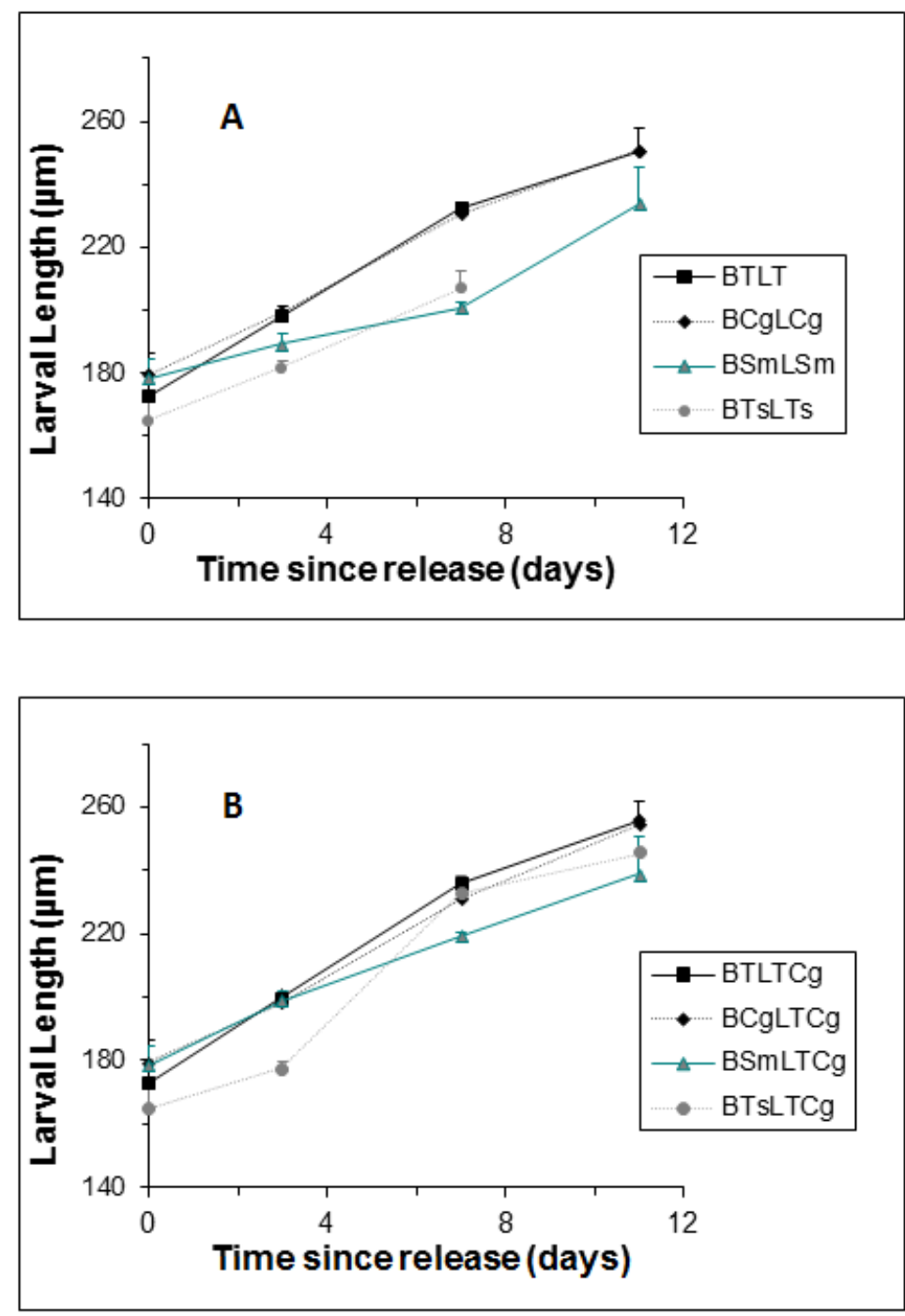
Figure 2. Mean daily growth (A), survival (B) and larval competence (C) ( \pm S.D.) of $O$. edulis larvae (L) fed different single diets: T: Tisochysis lutea, Cg: C. neogracile, Sm: S. marinoi and Ts: T. suecica or bi-specific diet TCg: T. lutea + C. neogracile, on day 11. Larvae were originated from parents fed similar single diets ( $\mathrm{T}, \mathrm{Cg}, \mathrm{Sm}$ or $\mathrm{Ts}$ ) during broodstock conditioning (B).

Significant differences $(\mathrm{p}<0.05)$ among treatments are denoted by different letters.
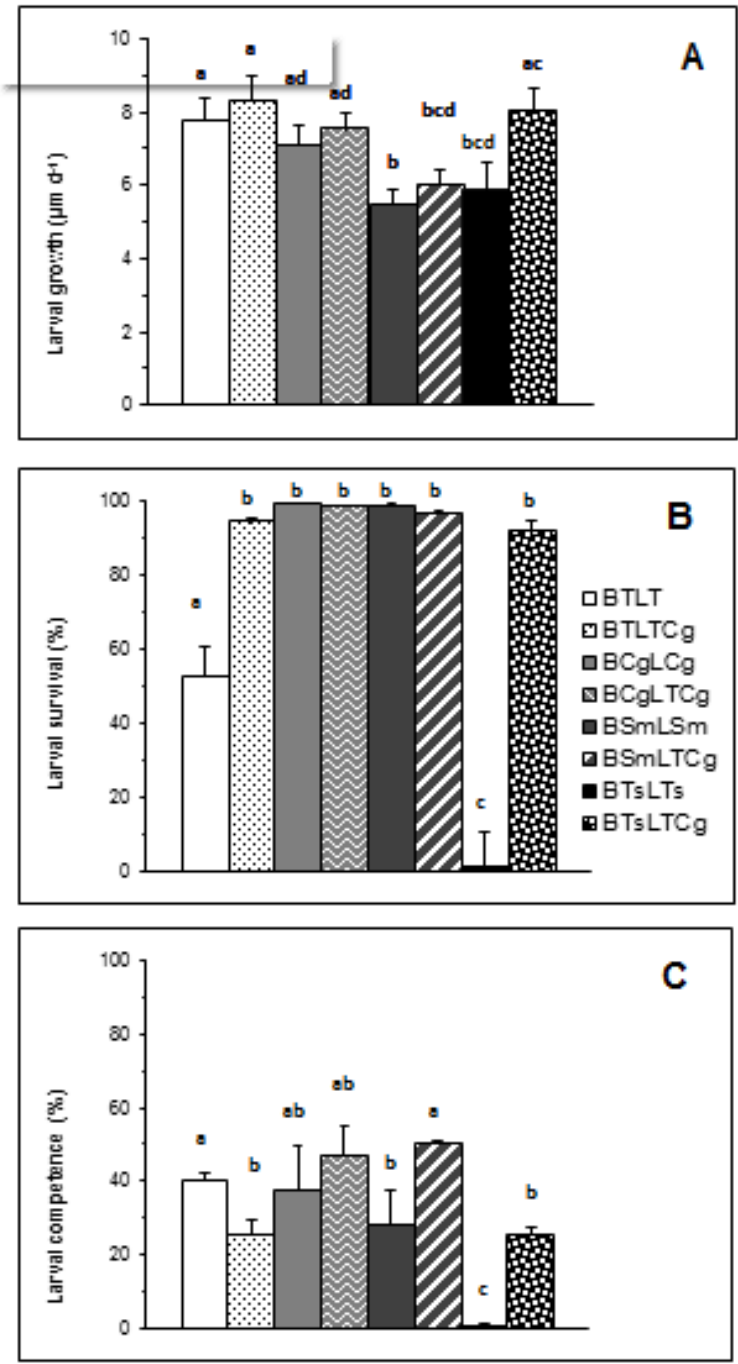

=- - 
Figure 3. Regression analysis of larval development indicators and main fatty acids (AA, EPA, DHA) absolute contents in 11d-old O. edulis: A daily growth of larvae fed three different single diets (Tisochrysis lutea: solid line Chaetoceros neogracile: broken line and Skeletonema marinoï: dotted line); B daily growth of larvae fed mixed $\operatorname{diet} T$. lutea plus $C$. neogracile; C larval competence of larvae (\% eyed larvae) fed three different single diets (T. lutea: solid line C. neogracile: broken line and S. marinö̈: dotted line); D competence of larvae fed mixed diet T. lutea plus C. neogracile.

Such regression was not evaluated for survival due to low differences between most of the conditions $(>90 \%)$.

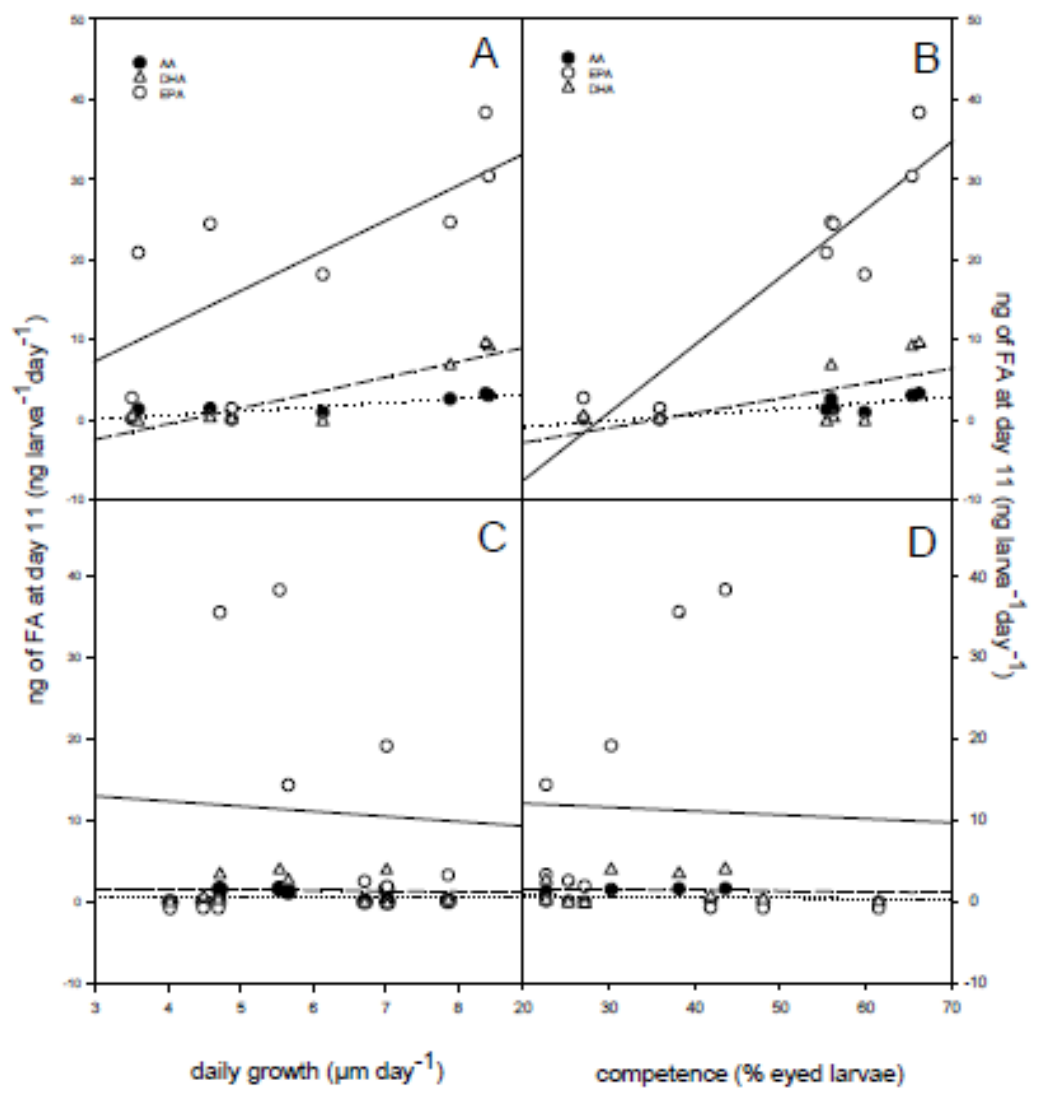

